\title{
PHOTOGRAMMETRY-DERIVED ORTHOIMAGERY AND ELEVATION FOR WAINWRIGHT, ALASKA, COLLECTED AUGUST 3, 2021
}

Richard M. Buzard, Daniel Heiner, Jacquelyn R. Overbeck, and Roberta J.T. Glenn

Raw Data File 2021-18
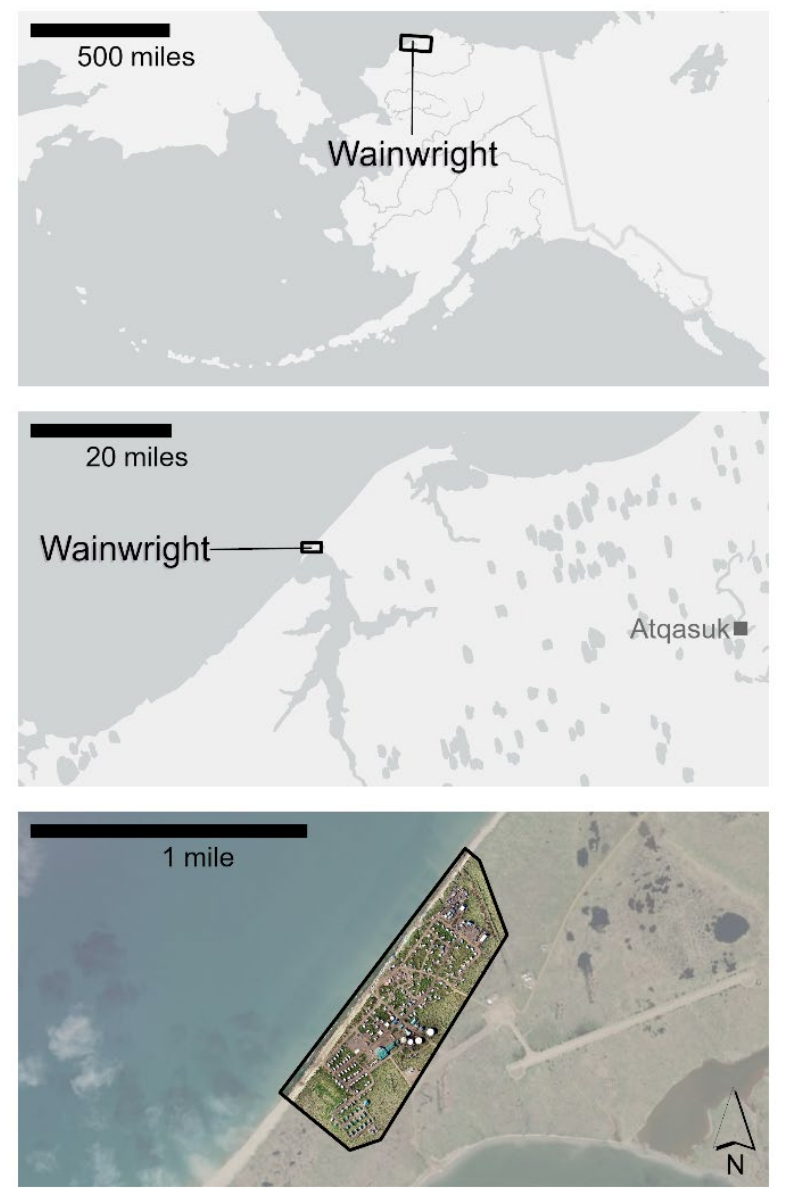

Location map of survey area with orthoimage

This report has not been reviewed for technical content or for conformity to the editorial standards of DGGS.

2021

STATE OF ALASKA

DEPARTMENT OF NATURAL RESOURCES

DIVISION OF GEOLOGICAL \& GEOPHYSICAL SURVEYS
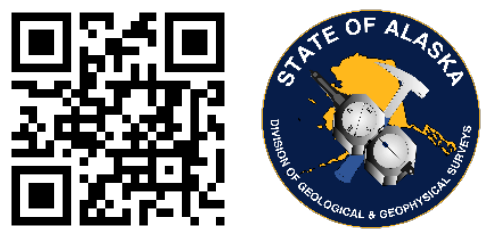
STATE OF ALASKA

Mike Dunleavy, Governor

DEPARTMENT OF NATURAL RESOURCES

Corri A. Feige, Commissioner

\section{DIVISION OF GEOLOGICAL \& GEOPHYSICAL SURVEYS}

Steve Masterman, State Geologist \& Director

Publications produced by the Division of Geological \& Geophysical Surveys are available to download from the DGGS website (dggs.alaska.gov). Publications on hard-copy or digital media can be examined or purchased in the Fairbanks office:

\section{Alaska Division of Geological \& Geophysical Surveys (DGGS)}

3354 College Road | Fairbanks, Alaska 99709-3707

Phone: 907.451 .5010 | Fax 907.451.5050

dggspubs@alaska.gov | dggs.alaska.gov

DGGS publications are also available at:

Alaska State Library, Historical

Collections \& Talking Book Center

395 Whittier Street

Juneau, Alaska 99801

Alaska Resource Library and

Information Services (ARLIS)

3150 C Street, Suite 100

Anchorage, Alaska 99503

\section{Suggested citation:}

Buzard, R.M., Heiner, Daniel, Overbeck, J.R., and Glenn, R.J.T., 2021, Photogrammetry-derived orthoimagery and elevation for Wainwright, Alaska, collected August 3, 2021: Alaska Division of Geological \& Geophysical Surveys Raw Data File 2021-18, 4 p.

https://doi.org/10.14509/30791

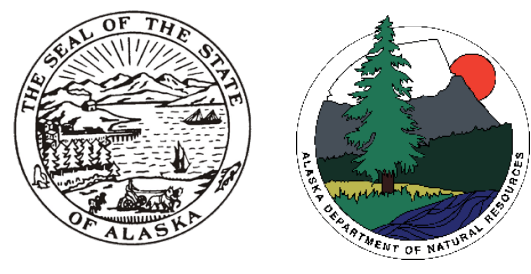




\section{PHOTOGRAMMETRY-DERIVED ORTHOIMAGERY AND ELEVATION FOR WAINWRIGHT, ALASKA, COLLECTED AUGUST 3, 2021}

Richard M. Buzard ${ }^{1}$, Daniel Heiner ${ }^{2}$, Jacquelyn R. Overbeck¹, and Roberta J.T. Glenn²

\section{INTRODUCTION}

The State of Alaska Division of Geological \& Geophysical Surveys (DGGS) collected low-altitude aerial images from an unmanned aerial vehicle (UAV) on August 3, 2021 and used Structure-from-Motion (SfM) photogrammetry to produce a digital surface model (DSM) and orthoimage of Wainwright (fig. 1). The orthoimage and elevation data are for assessing coastal hazards and changes. We used Trimble Business Center to process the Global Navigation Satellite System (GNSS) data used for positional control. We used Agisoft Metashape Professional to process the photogrammetry data. These products are released as a Raw Data File with an open end-user license. All files can be downloaded from doi.org/10.14509/30791 or elevation.alaska.gov.

\section{LIST OF DELIVERABLES}

- Orthoimage

- Digital Surface Model (DSM)

- Metadata
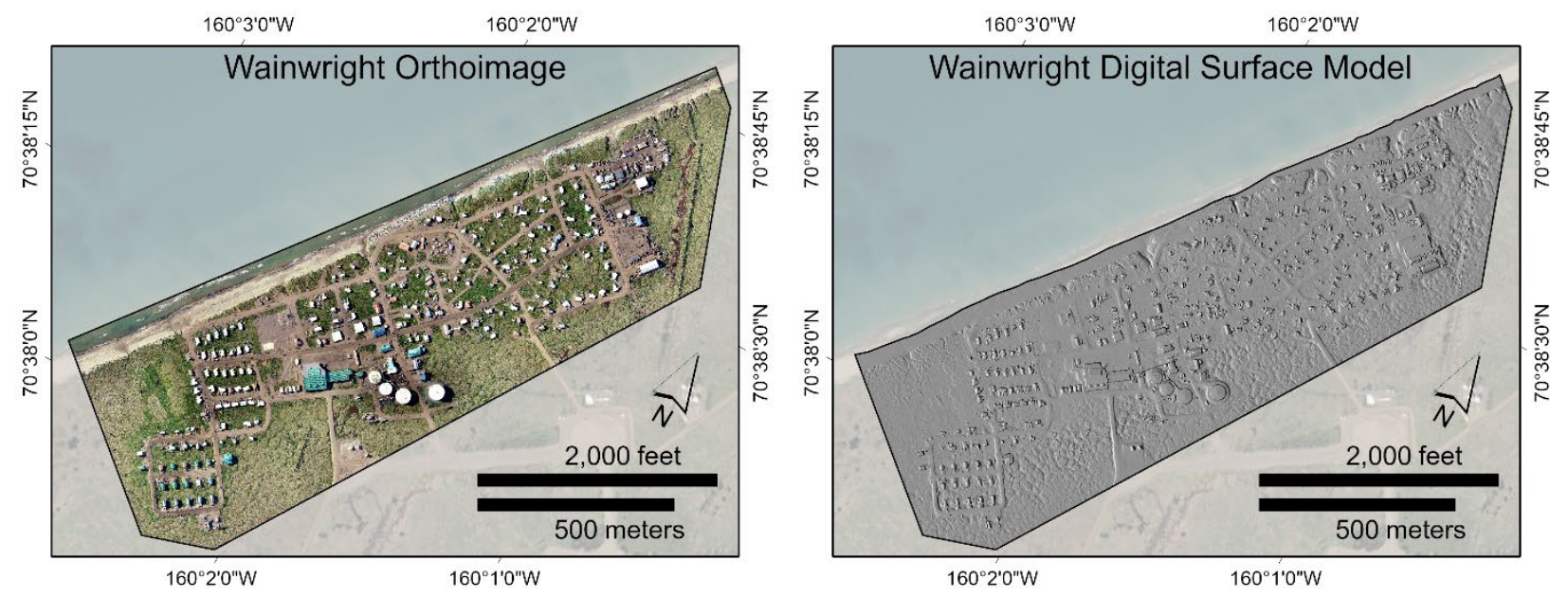

Figure 1. Extent of orthoimage (left) and DSM (right) for Wainwright.

\footnotetext{
${ }^{1}$ Alaska Division of Geological \& Geophysical Surveys, 3354 College Road, Fairbanks, AK 99709.

${ }^{2}$ North Slope Borough Planning \& Community Services-GIS, P.O. Box 69, Barrow, AK 99723.
} 


\section{MISSION PLAN}

\section{Aerial Photogrammetric Survey Details}

DGGS used a DJI Phantom 4 RTK UAV with a FC6310R camera model (8.8 $\mathrm{mm}$ lens) to collect 20 -megapixel JPEG photographs (5472 $\times 3648$ pixels per image). We flew the aerial survey with 70 percent sidelap and 80 percent frontlap, $120 \mathrm{~m}$ above the ground at $7.9 \mathrm{~m} / \mathrm{s}$, with nadir camera orientation stabilized by a 3-axis gimbal. The resulting images cover 0.94 $\mathrm{km}^{2}$ with ground sampling distance (GSD) of approximately $0.03 \mathrm{~m}$.

\section{Weather and Photo Conditions}

DGGS conducted flights on August 3, 2021, from 6:40 to 7:50 PM AKDT. The operator returned the UAV three times to change batteries. The weather was favorable with no clouds, no rain, and light wind. No abnormalities were observed during the flights.

\section{SURVEY AND PROCESSING REPORT}

\section{Ground Survey Details}

DGGS set up a GNSS base station using a Trimble R10 receiver sampling at $5 \mathrm{~Hz}$. The base was installed over a benchmark with a published solution (found at www.ngs.noaa.gov/OPUS/ getDatasheet.jsp?PID=BBHM25). This provided real-time kinematic (RTK) corrections to the UAV and Trimble R8s GNSS receiver. DGGS measured 18 photo-identifiable points with the R8s. We derived the corrected base position using the Online Positioning User Service (found at www.ngs.noaa.gov/OPUS/) and post-processed the R8s positions in Trimble Business Center.

\section{Photogrammetric Dataset Processing}

The UAV did not maintain RTK connection with the Trimble R10 base station. We apply a post-processing kinematic correction using RTKLIB (an open-source GNSS processing software found at www.rtklib.com). The UAV GNSS receiver samples at $5 \mathrm{~Hz}$, rather than at image acquisition times. We interpolate the corrected positions at image timestamps to derive coordinates. The image timestamp metadata also contains orientation information to support the lever arm correction that adjusts coordinates from the GNSS receiver to the camera. We compute the interpolation and lever arm correction using the worksheet found at www.aerotas.com/phantom-4-rtk-ppk-processing-workflow.

DGGS processed images in Agisoft Metashape Professional software (Version 1.6.3 build 10732). We masked image corners where shadows and image warping were disruptive. Processing steps included aligning images, identifying ground control points (GCPs), manually cleaning the sparse point cloud, optimizing the bundle block adjustment (refining camera positions and lens distortion parameters), constructing the dense point cloud, building the DSM, and creating the orthomosaic image. We used five GCPs to create the model, leaving thirteen survey check points.

\section{Orthoimagery}

The orthoimagery is a three-band (red, green, blue) 8-bit unsigned GeoTIFF file with a GSD of $0.035 \mathrm{~m}$ per pixel and the "No Data" value is set to 0 .

\section{Digital Surface Model}

The DSM represents surface elevations such as the height of vegetation and buildings.

Water bodies can introduce noise. We manually delineated the ocean boundary to restrict 
the DSM to the land. The DSM is a single-band, 32-bit floating point GeoTIFF file with a GSD of $0.069 \mathrm{~m}$ and the "No Data" value is set to $-3.4028231 \times 10^{38}$.

\section{ACCURACY REPORT}

\section{Coordinate System and Datum}

All data are processed and delivered in NAD83 (2011) UTM Zone 4N and vertical datum NAVD88 (GEOID12B).

\section{Horizontal Accuracy}

We quantify the horizontal accuracy of the DSM and orthoimage by comparing the known locations of 13 photo-identifiable check points measured with GNSS against their modeled locations in the photogrammetric products (fig. 2). X and Y errors are calculated as the root-mean-square (RMS) error of offsets. The total horizontal error is the root-sumsquare error of X and Y RMS errors, $0.052 \mathrm{~m}$ (table 1).

\section{Vertical Accuracy}

We assess the vertical accuracy of the DSM using the same check points. The RMS error of $\mathrm{Z}$ offsets is $0.105 \mathrm{~m}$ (table 1 ). The total error of the DSM (X, Y, and Z) is $0.117 \mathrm{~m}$.

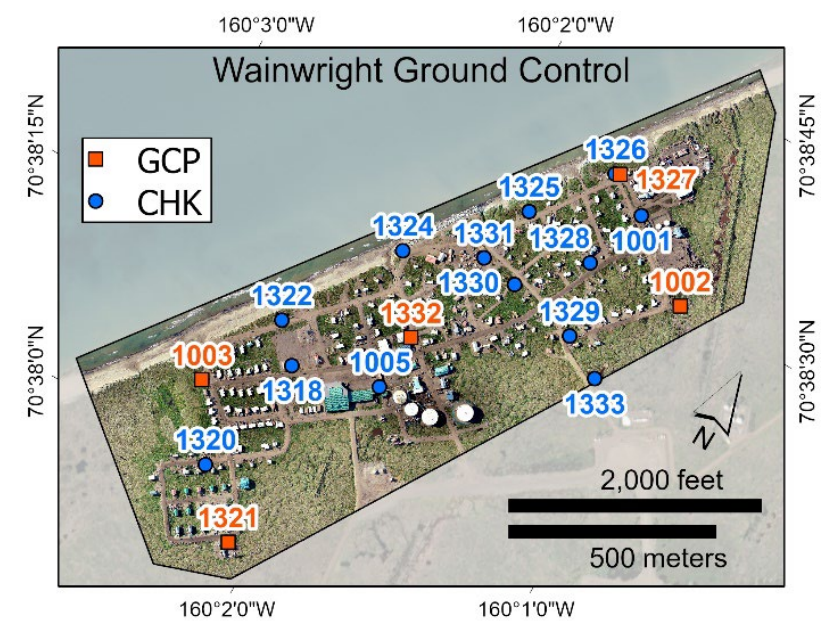

Figure 2. Location of photo-identifiable ground control points (GCPs; red) and check points (CHK; blue). 
Table 1. Check point coordinates and offsets from orthoimage and DSM.

\begin{tabular}{|c|c|c|c|c|c|c|}
\hline $\begin{array}{l}\text { Check } \\
\text { Point }\end{array}$ & Easting & Northing & Elevation & $\begin{array}{c}\text { X Offset } \\
(\mathrm{m})\end{array}$ & $\begin{array}{c}\begin{array}{c}\text { Y Offset } \\
(\mathbf{m})\end{array} \\
\end{array}$ & $\begin{array}{c}\begin{array}{c}\text { Z Offset } \\
(\mathrm{m})\end{array} \\
\end{array}$ \\
\hline 1001 & 462156.081 & 7837881.157 & 8.548 & 0.002 & -0.020 & 0.061 \\
\hline 1005 & 461816.088 & 7837210.159 & 9.178 & 0.034 & 0.031 & -0.219 \\
\hline 1318 & 461608.429 & 7837148.909 & 7.913 & 0.016 & 0.043 & -0.199 \\
\hline 1320 & 461547.509 & 7836839.662 & 8.023 & -0.009 & -0.042 & -0.018 \\
\hline 1322 & 461532.396 & 7837231.089 & 6.652 & -0.056 & 0.013 & -0.190 \\
\hline 1324 & 461700.920 & 7837521.184 & 6.945 & -0.041 & 0.014 & -0.089 \\
\hline 1325 & 461916.866 & 7837754.351 & 7.437 & -0.060 & -0.026 & 0.028 \\
\hline 1326 & 462051.487 & 7837935.907 & 7.574 & -0.024 & -0.039 & 0.051 \\
\hline 1328 & 462105.590 & 7837721.380 & 9.839 & -0.025 & -0.004 & 0.019 \\
\hline 1329 & 462150.713 & 7837543.784 & 12.706 & -0.005 & -0.070 & 0.000 \\
\hline 1330 & 461974.250 & 7837584.698 & 10.424 & 0.003 & -0.015 & -0.001 \\
\hline 1331 & 461879.196 & 7837604.015 & 9.444 & -0.068 & -0.065 & -0.005 \\
\hline 1333 & 462254.236 & 7837485.474 & 15.996 & -0.023 & -0.038 & -0.064 \\
\hline & & & Mean & -0.020 & -0.017 & -0.048 \\
\hline & & & Standard Deviation & 0.031 & 0.035 & 0.097 \\
\hline & & & Range & 0.102 & 0.113 & 0.280 \\
\hline & & & Root Mean Square Error & 0.035 & 0.038 & 0.105 \\
\hline & & & Total Error & \multicolumn{2}{|c|}{$\begin{array}{c}0.052 \\
(X Y)\end{array}$} & $\begin{array}{l}0.117 \\
(\mathrm{XYZ}) \\
\end{array}$ \\
\hline
\end{tabular}

\section{Data Consistency and Completeness}

DGGS visually inspected the orthoimage for data errors such as shifts, seamline mismatches, and water noise overlapping land. There were no significantly erroneous areas that required repair. The shadows of power poles caused shallow, linear divots in the DSM. Other visual errors common to these SfM photogrammetry products include discontinuous powerlines, blurriness near high-angle features like buildings, and distortion at water boundaries. Bright objects like metal roofs and white paint can cause overexposure, leading to spurious elevation points.

\section{ACKNOWLEDGEMENTS}

This work was funded by the State of Alaska's Arctic Strategic Transportation and Resources (ASTAR) Capital Improvement Project. 